\title{
The boulder berm of Punta Saguerra (Taranto, Italy): a morphological imprint of the Rossano Calabro tsunami of April 24, 1836?
}

\author{
G. Mastronuzzi ${ }^{1,2}$ and C. Pignatelli ${ }^{1,2}$ \\ ${ }^{1}$ Dipartimento di Scienze della Terra e Geoambientali, Università degli Studi “Aldo Moro”, Bari \\ ${ }^{2}$ LAGAT-TA Laboratorio Gis Geoambientale e di Telerilevamento-Taranto, II Facoltà di Scienze Matematiche Fisiche e Naturali, \\ Università degli Studi “Aldo Moro”, Bari
}

(Received November 2, 2010; Revised August 18, 2011; Accepted August 24, 2011; Online published October 24, 2012)

\begin{abstract}
An extended berm of calcarenitic boulders is recognisable at Punta Saguerra, few kilometres south of Taranto (Apulia, Italy) while isolated boulders are sparse in other near localities. The berm is at 2-5 m above present sea level (a.p.s.l), on a rocky headland gently sloping toward the sea; it is separated from the coastline by a large terrace. A detailed study of its stratigraphy and its morphology has been performed in order to define its depositional mechanism; in particular, integrated DGPS and Laser Scanner surveys have provided precise details of each boulder: position, size and distance from the shoreline. The accumulation is constitute of boulders up to 30 tons, which locally are arranged in rows of embricated patterns. The surfaces of the biggest boulders are characterised by biogenic encrustations and by solution potholes that indicate their intertidal/adlittoral/spray zone provenience. Based on direct observations of each boulder (size, shape, weight and long axis azimuth), together with hydrodynamic equations it is possible to hypothesize the extreme event—geodynamic or meteorologicalwhich was responsible for this singular accumulation. AMS age determinations on Vermetid sp. sampled on boulder surfaces and chronicle suggest that the accumulation may be attributed to the tsunami generated by the strong earthquake that occurred on April 24, 1836, the epicentre of which has been localised near Rossano Calabro, along the Ionian coast of northern Calabria.
\end{abstract}

Key words: Boulder berm, rocky coast, tsunami, Apulia.

\section{Introduction}

Many authors have described the presence of megaboulders along coasts around the world as one of the main evidence of the impact of catastrophic waves of either geological (tsunami) or meteorological (hurricanes, storms) origin (for instance: Hearty, 1997; Mastronuzzi and Sansò, 2000, 2004; Scheffers, 2002, 2004; Noormets et al., 2004; Williams and Hall, 2004; Kelletat et al., 2005; Hall et al., 2006; Goto et al., 2007, 2010). At present, the diatribe about the individuation of the type of mechanism responsible for their placement is still open. Recent surveys performed some days after the occurrence of the Sunda tsunami on December 26, 2004 recognized that at Pakarang Cape, Thailand, the inland scattering of mega-boulders had resulted from this tsunami (Goto et al., 2007). On the other hand, the affirmation that the presence of mega-boulders along the coasts is always evidence of a tsunami impact is a matter of debate (for instance: Moore and Moore, 1984; Bryant and Young, 1996; Hearty, 1997; Felton et al., 2000; Mastronuzzi et al., 2006; Switzer and Burston, 2010). Nevertheless, the local morpho-bathymetry, litho-structural features and the local wave climate, all together condition the effect of a wave impact, whatever its generating mechanism may be. Different coastal areas of the Pacific, Atlantic

Copyright (C) The Society of Geomagnetism and Earth, Planetary and Space Sciences (SGEPSS); The Seismological Society of Japan; The Volcanological Society of Japan; The Geodetic Society of Japan; The Japanese Society for Planetary Sciences; TERRAPUB.

doi:10.5047/eps.2011.08.018 and Indian oceans are characterized by impacting "normal" storm waves some ten meters high able to move boulders (Moberly and Chamberlain, 1964; Dollar, 1982; Dollar and Tribble, 1993; Williams and Hall, 2004; Hall et al., 2006; Holliday et al., 2006; Hansom et al., 2008). A recent survey highlights that, locally, a tsunami can also be characterized by a wave some ten meters high, but this is not the normality (Lavigne et al., 2006); more frequent is the possibility that an impacting wave can run inland, rising along the coastal slope and defining a run-up of some ten meters. On the other hand, a tsunami is characterized by an impressive energy connected not only to the wave height but also to the wave period and its length; the possibility to release energy corresponds to its capability to pickup in charge while transporting a large quantity of heterometric material as the March 11, 2011 Japanese tsunami shown to all the world.

Recent surveys performed along the coast of the Mediterranean basin evidenced landward the presence of boulders, arranged in fields and/or ridges and emplaced at various distances from the coastline. The cause of the displacement of the boulders is generally ascribed to a tsunami impact (Mastronuzzi and Sansò, 2000, 2004; Kelletat and Schellmann, 2002; Morhange et al., 2006; Vött et al., 2006; Mastronuzzi et al., 2007a; Scicchitano et al., 2007; Scheffers and Scheffers, 2007; Maouche et al., 2009), although, in some cases boulder dislocation is directly recognised to be caused by the recent impact of storms generated by strong winds (Mastronuzzi and Sansò, 2004; Barbano 


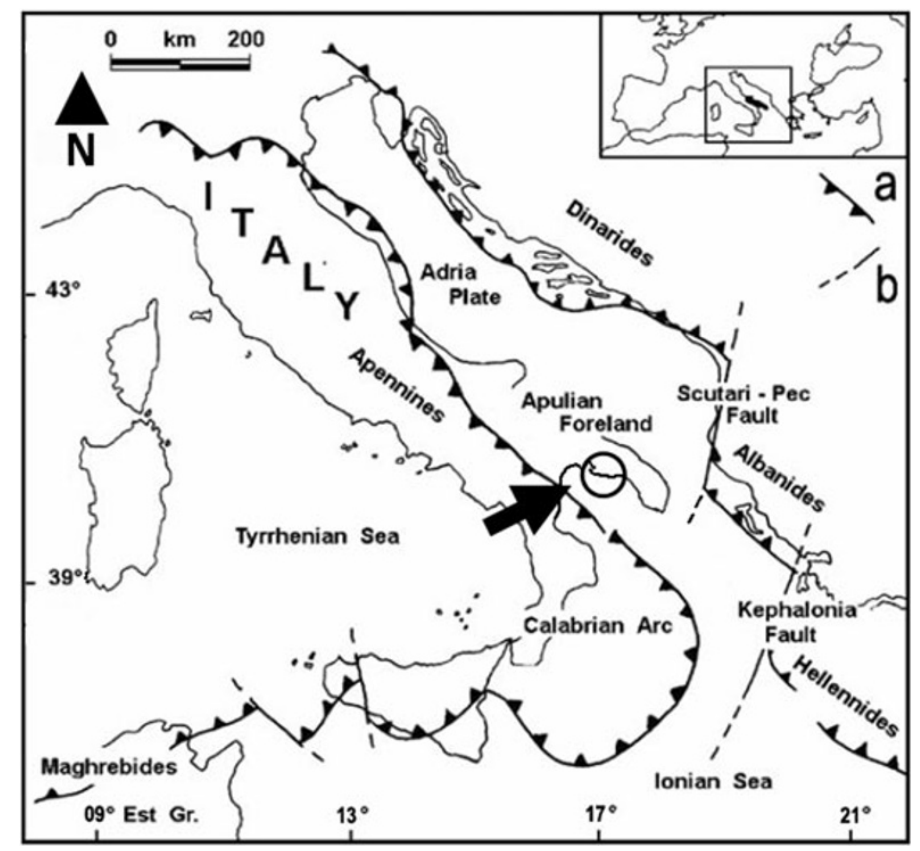

Fig. 1. Localisation of the studied area in the centre of the Mediterranean Basin; (a) outer limit of overthrust fronts; (b) main transcurrent faults.

et al., 2010). Even though, from the analysis of the morphological and climatic features of the Mediterranean basin, it can be inferred that "normal" exceptional waves are not able to dislodge, transport and scatter inland boulders with weights exceeding 1.4/1.8 tons (Mastronuzzi et al., 2006). Based on the available data, it has been possible to improve the assessment of coastal hazards (Mastronuzzi and Sansò, 2006) and to realize a hydrodynamic equation that permitted to evaluate the maximum flooding possible, starting with the size of the deposited boulders as a consequence of a tsunami impact (Pignatelli et al., 2009). Together, local census data, surveys and knowledge of the areas in which boulders were accumulated by a tsunami, are extremely important in the definition of a tsunami coastal hazard and in the redaction of the map of coastal risk. An extended boulders accumulation has been identified along the rocky coast of Punta Saguerra (= Cape Saguerra), located not far from the city of Taranto, along the Ionian coast of the Apulian region (Southern Italy), whereas isolated boulders have been recognised in other nearby localities (Fig. 1). In the following pages the detailed survey of the features of the main accumulation and its chronological attribution are presented and discussed in order to identify its generative event.

\section{Geodynamic Settings}

The Mediterranean area represents the collision zone between the European and African plates; it comprises a number of geodynamic regions affected by different seismic activities. In particular, in the centre of the Mediterranean basin, at the bottom of the Ionian sea, the multiple plate junction of Africa, Adria and the Aegean, define different types of plate boundaries that came about through collision, subduction, transformational faulting and spreading. These plates support a geodynamic model that assumes a slow NNW-SSE convergence between the Eurasia and AfricaAdria continental plates (for istance see: Chiarabba et al.,
2005; Di Bucci et al., 2009, 2010). The connected seismicity has been responsible for generating numerous earthquakes which can explains the recurrence of the historical tsunamis that have hit the Italian and other Mediterranean coasts over the last millennium (Soloviev, 1990; Tinti and Maramai, 1996; Mastronuzzi, 2010). In the centre of the Mediterranean basin, the Apulian region represents a part of the emerged foreland of both Appenninic and Dinaric orogens (Fig. 1); it is slightly deformed and affected by Appenninic and anti-Appenninic trending faults which sub-divide it into five main structural blocks characterized by different long-term uplift rates decreasing from north to south (for instance: Del Gaudio et al., 2005; Ferranti et al., 2006; Mastronuzzi et al., 2007b and references therein). The front of the Appeninic thrust runs emerged NNW-SSE, about parallel to the Apulian foreland; in the submerged part of the Taranto Gulf it is almost parallel to the Apulian escarpment up to the latitude of Kephalonia Island, where it turns SW (Butler et al., 2004). The whole area comprised between the Appeninic thrust front and the emerged part of the Calabrian Arc is characterized by high seismic activity (Jenny et al., 2006); an important part of the historical earthquake epicentres is located in the Taranto Gulf, which is up to 2,500 m deep (Fig. 2).

On the other hand, along the eastern part of the Adriatic Sea, the front of the Dinarides, Albanides and Hellenides chains runs about parallel to the coastline crossed by main faults. The highly seismic Kephalonia right-lateral strikeslip fault represents the limit between the Euroasian and the Aegean-Asian plates (Pondrelli et al., 2002). The seismic activity along this structural alignment is probably responsible for the seismic sequence of 1743 that generated the tsunami whose deposits have been recognised along the southernmost part of Apulia (Mastronuzzi et al., 2007a). Hence, this region is surrounded by seismically active zones characterized by a high potential for generating submarine 


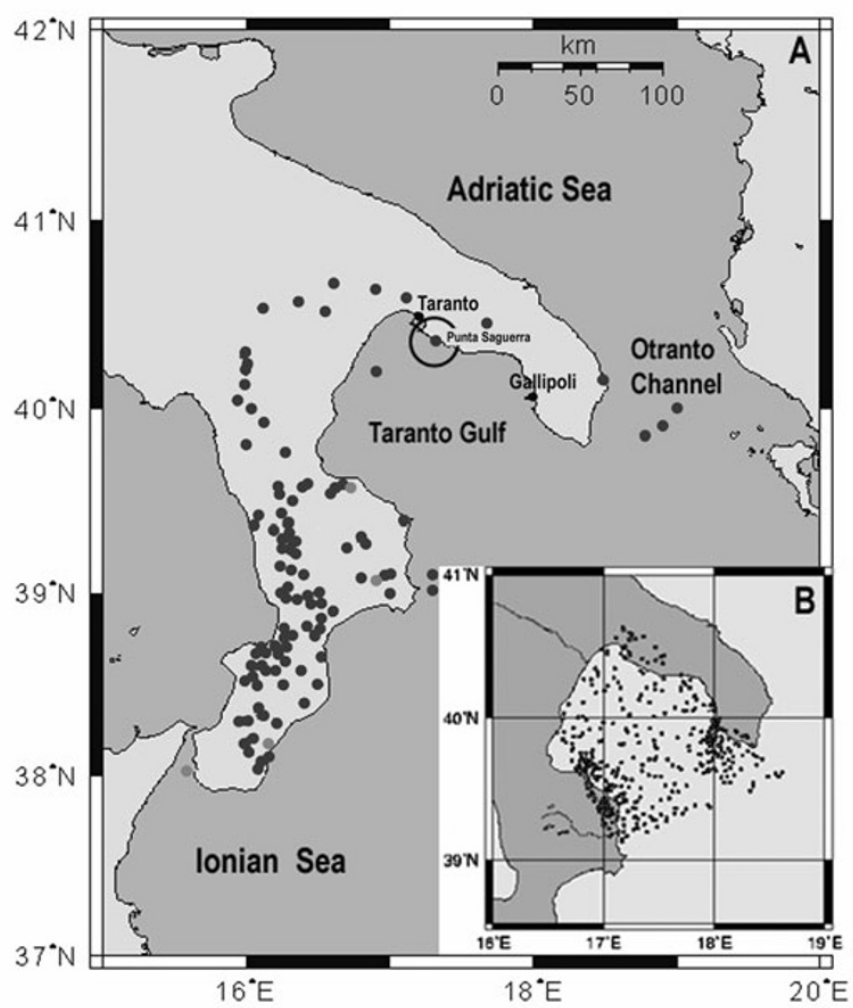

Fig. 2. Seismicity in the area around the Taranto Gulf: A—epicentre of the earthquake occurring between 951 A.D.-2000 A.D.; B-epicentres of earthquakes in the last 40 years. Of interest are the earthquakes occurring offshore of Gallipoli (May $7,1983 M=5.3$ ) and the seismic sequence with an epicentre $20 \mathrm{~km}$ from Rossano (April 17, $2002 M=4.7$ ).

earthquakes and consequently large tsunamis, especially in the near shore zone. Furthermore, the Mediterranean Basin is very narrow and, if generated, a tsunami can rapidly reach every coast, thus causing catastrophic effects on a local scale (Mastronuzzi et al., 2006).

If these geodynamic features constitute the main source of past tsunamis in the Mediterranean Basin, it is nevertheless necessary to consider other possible sources of extreme waves such as coastal and/or submarine landslides that can be often generated by seismic mechanisms, volcanic eruptions or storms. In fact, in the absence of an extended continental shelf, the proximity of the high mountain chains to the continental slope that is connected to deep abyssal plains-up to $5,000 \mathrm{~m}$ in the Ionian Sea-make it possible for a large submarine slide to move an enormous quantity of solid material able to compress a high volume of water (Mastronuzzi, 2010) (Fig. 3).

Just the Calabria region shows a narrow continental shelf with a steep mountain chain which dips directly into the sea. Seismic activity that characterized the Calabrian Arc and the Apenninic chain is a favourable condition to determine landslides possibly falling into the deep area of the surrounding seas. Based on the surveys of several important submarine landslides along the Calabrian continental slope (Colizza et al., 2005) it was hypothesized that they could be also a consequence of the seismic sequence that occurred inland between the end of 1456 and the beginning of 1457 . This last event generated the tsunami to which is attributed the accumulation of the boulders immediately north of the city of Gallipoli (Mastronuzzi and Sansò, 2000). Moreover, in the past, along the Tyrrenian side of Calabria, the sequence of five earthquakes that occurred in 1783, between February 1 and March 28, triggered a large landslide at the top of Monte Paci; its collapse in to the sea generated the large tsunami that on February 6 destroyed the city of Scilla, killing about 1,500 people. Large landslides have also occurred along the north African coasts as reported by Cita and Aloisi (2000).

\section{Morphology of the Coastal Area: Description and Analytic Methods}

The entire coastal area south of Taranto is characterized by a number of marine terraces in staircase-like arrangement between elevations of about $400 \mathrm{~m}$ and the mean sea level (m.s.l.). This is the result of the superimposition of regional uplift and of the glacio-eustatic sea level changes that have occurred from the Middle Pleistocene to the present. The Middle-Late Pleistocene stratigraphic sequence crops out along the coast; it can be synthetically represented by silty clay Plio-Pleistocene in age, capped with well-cemented transgressive algal calcarenites, sometimes in partial overlapping, ascribed to the Upper Pleistocene (Belluomini et al., 2002 and references therein). Generally, at large scale, the coast has a linear pattern; however, the area is marked by deep inlets, limited by a more or less extended cape, that correspond to continental water interstratal incisions filled by the sea during the Holocene transgression (Mastronuzzi and Sansò, 1998; Lambeck et al., 2004). Along the microtidal coast of this area (tides never exceeding $0.70 \mathrm{~m}$ ) the sea level is still in rising with a rate 


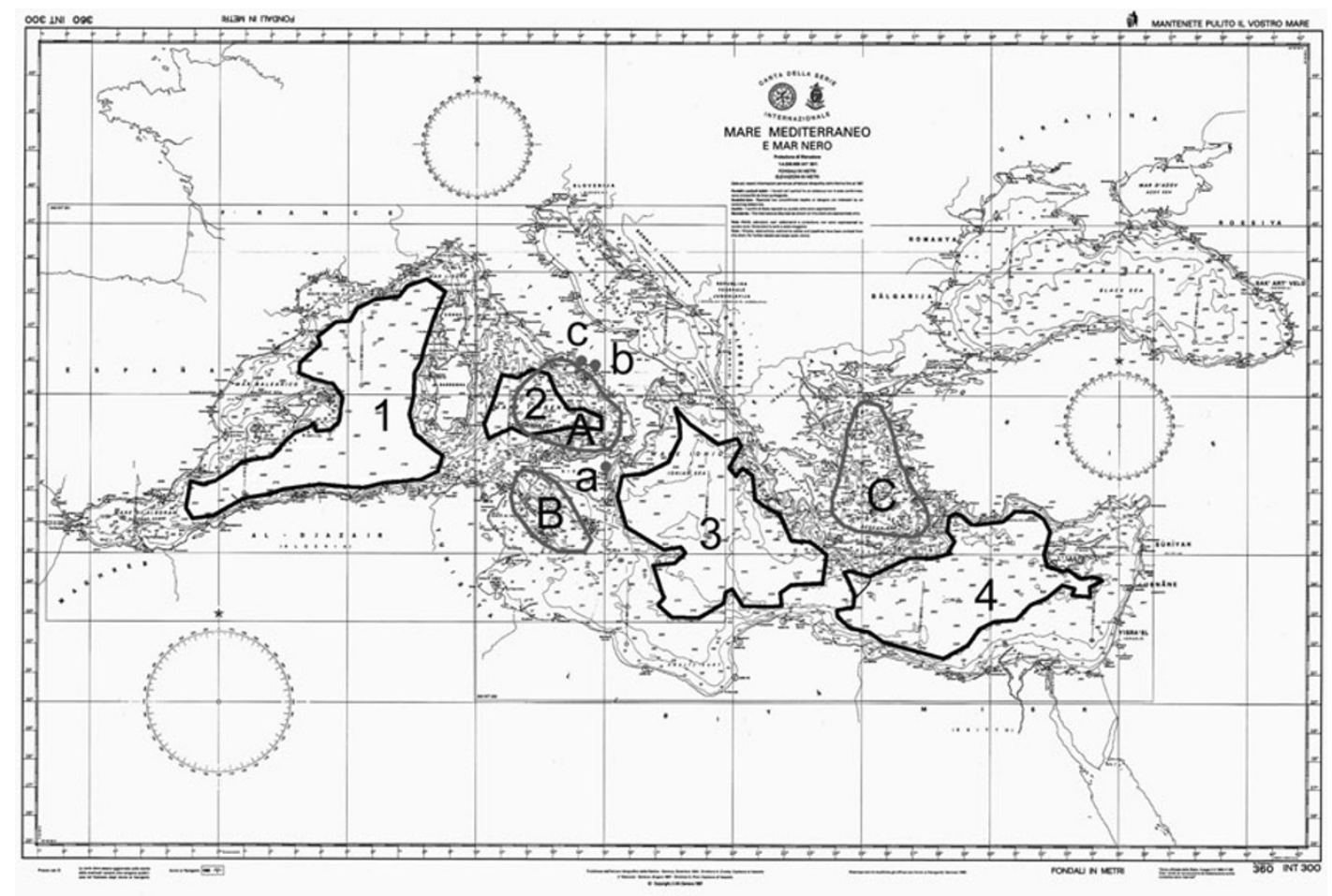

Fig. 3. Deeper areas (more than $2000 \mathrm{~m}$ ) and main volcanic districts in the Mediterranean Basin; it is evident the short extension of the continental shelf between high mountain chains and shelf break, as well as the gradient of the continental slope. 1-Sardinia sea (max c.a $3000 \mathrm{~m}$ ); 2 - Tyrrhenian sea (max c.a $3500 \mathrm{~m}) ; 3$ - Ionian sea (max c.a $5000 \mathrm{~m})$; 4 -eastern basin (max c.a $4000 \mathrm{~m}$ ); A-Tyrrhenian district; B-Sicily Channel district; C-Aegean district; a-Mount Etna volcano; b-Mount Somma-Vesuvio volcano; c-Campi Flegrei volcano (chart n. 360 INT 300 Istituto Idrografico della Marina, Genova, Italy) (from Mastronuzzi, 2010).

of $0.5-1.0 \mathrm{~mm} / \mathrm{year}$ as suggested by archaeological markers (Auriemma et al., 2004).

The lowermost marine terrace is constituted by wellcemented bio-algal calcarenite marked by the presence of abundant mollusc, briozoa and coral, attributed to the last interglacial time $(=$ LIT) MIS 5; the textural features correspond to a specific weight determined in the laboratory ranging from $2.20-2.35 \mathrm{~g} / \mathrm{m}^{3}$. The calcarenitic local bedrock presents very long fractures that become wider toward the coastline. Several of these fractures are parallel to the shoreline; some of these are also oriented SSW-NNE, about orthogonal to the most frequent sea-storm impact direction. Generally, they have been correlated to the recent tectonic history responsible for the general tilting of the MIS 5 terraces from NNW to SSE, placed at about $20 \mathrm{~m}$ near Taranto and the approximate sea level near Gallipoli (Di Bucci et al., 2009, 2011). All the same, it is possible that the fractures near the coastline have been determinedor enlarged-by the continuous impact of the "normal" storm waves.

Frequently, boulders isolated or arranged in fields, are sparse both along the coast and in correspondence to the main capes. The most famous has been recognised approximately $60 \mathrm{~km}$ from Taranto in the Torre Squillace locality, near Gallipoli; thanks to ${ }^{14} \mathrm{C}$ age determinations and historic chronicles, its put in place has been attributed to the impact of a catastrophic wave that was arose on December 5, 1456 by a large submarine landslide generated by the strong seismic sequence that hit the entire south of Italy (Mastronuzzi and Sansò, 2000). Just, $20 \mathrm{~km}$ south of Taranto, in corre- spondence to the prominent Punta Saguerra, there is another large boulder accumulation arranged in a berm.

\subsection{Punta Saguerra boulder berm}

Punta Saguerra is a cape that extends out to sea about $200 \mathrm{~m}$ and is flanked by a deep inlet (Fig. 4). An analysis of the structural features of the local calcarenite has evidenced the main orientation of two sets of fractures: the first is oriented $142-190^{\circ} \mathrm{N}$ and the second $270-300^{\circ} \mathrm{N}$. The submerged part of the cape is characterised by an articulated sea bottom inclined off shore of about $6 \%$ up to $-30 \mathrm{~m}$; coastward it finishes in a quite vertical cliff whose foot is at $-3 /-5 \mathrm{~m}$ below present sea level, marked by the presence of discontinuous accumulation of collapsed boulders. The emerged part is characterized by a slightly undulating surface with a mean slope of about 6-7\% (Fig. 4(B)) and a maximum elevation of $11 \mathrm{~m}$ above the biological sea level (= a.b.s.l.) (sensu Laborel and Laborel-Deguen, 1994). Starting from the coastline it is possible to divide the cape in three different zones: ì-a terrace surface about $50 \mathrm{~m}$ wide at about 2-3 $\mathrm{m}$ a.b.s.l.; ì̀-a boulder berm leaning on a step placed between 2 and 5 meters a.b.s.l.; and ìì-a steeper terrace that reaches approximately $11 \mathrm{~m}$ a.b.s.l.

ì-The first zone has a convex profile bordered seaward by a trottoir (approx. $3 \mathrm{~m}$ wide) that marks the biological sea level and is bare of vegetation. In the spray zone, the surf bench is marked by small coalescent karstic potholes, giving place to pinnacle-like forms (spitzkarren) separated inward by gradually widening flat depressions. Some boulders from this articulated surface have been carved out and scattered inland; in fact, small isolated boulders placed 


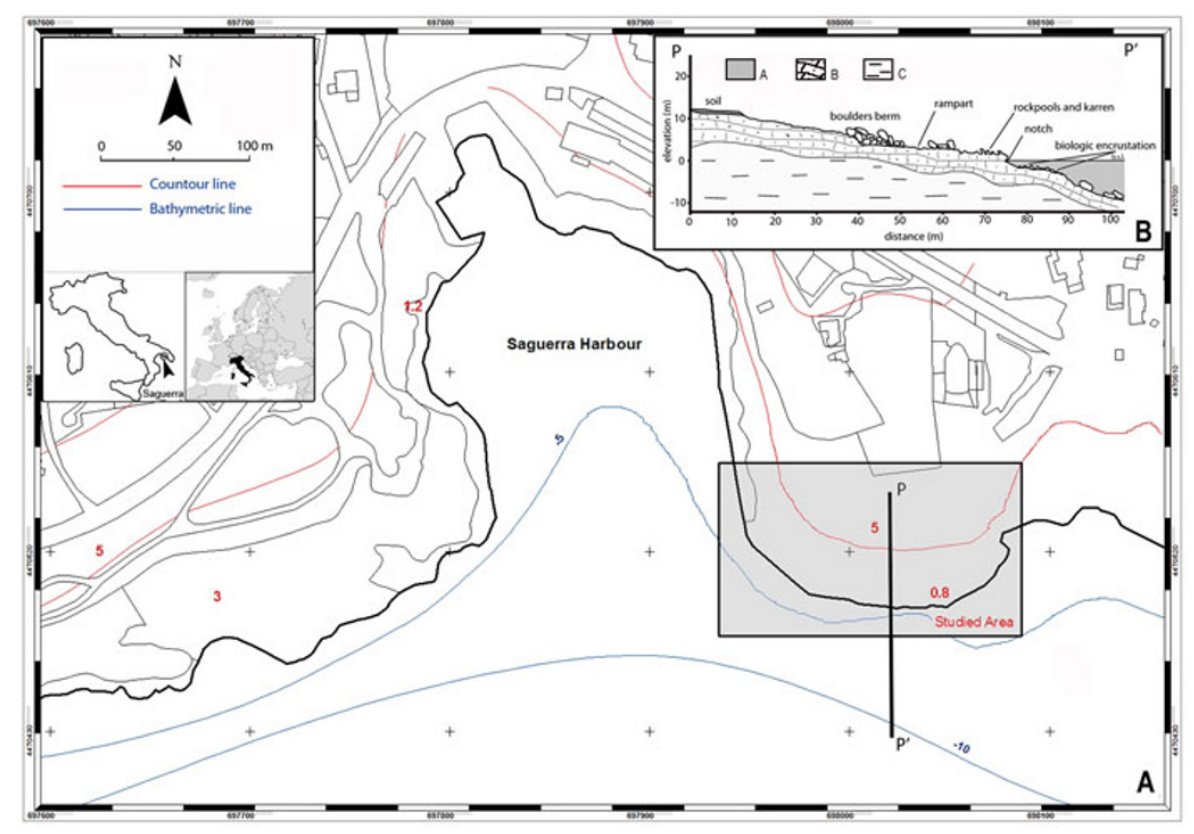

Fig. 4. Detailed location of Punta Saguerra (A) and geomorphological sketch (B). Legend: A—soil; B—Upper Pleistocene algal calcarenite; C—Plio Pleistocene silty clay.
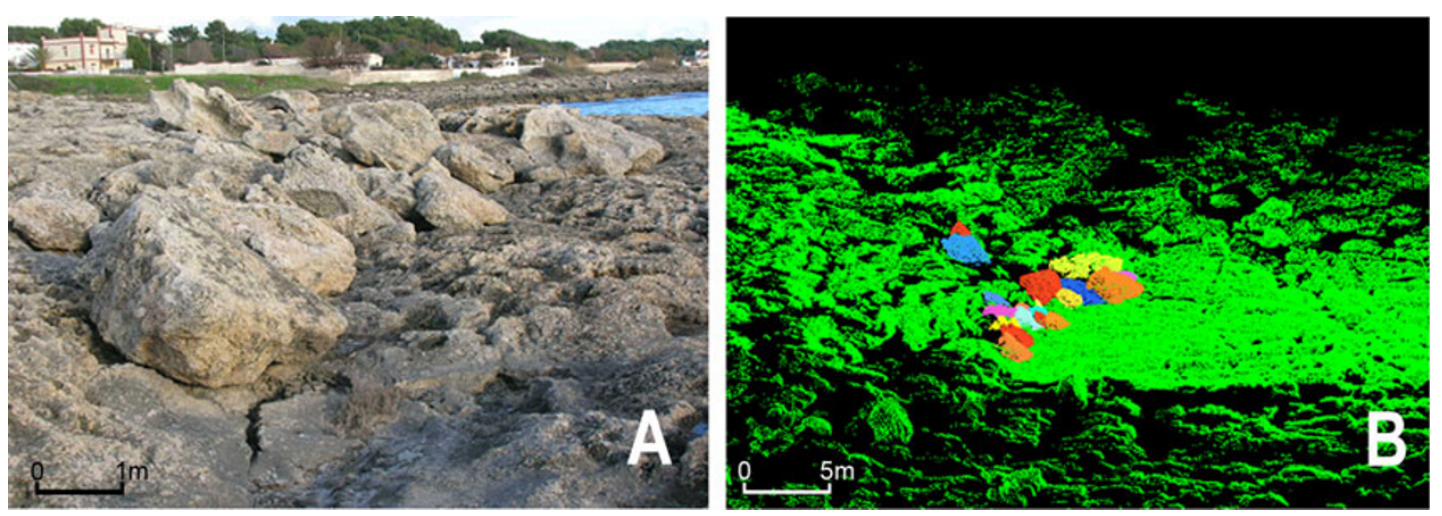

Fig. 5. The berm at Punta Saguerra (A) and elaboration 3D of the TLS survey (B).

in this zone are often not in equilibrium or imbricated in groups.

ì- The second zone shows a boulder berm that runs parallel to the present coastline for about $100 \mathrm{~m}$, at a distance ranging from 25 to $45 \mathrm{~m}$; the ridge leans on a low step shaped on the algal calcarenite (Fig. 5). Boulders have various sizes that range between $1.5 \times 0.4 \times 0.8 \mathrm{~m}$ to $3.7 \times 3.1 \times 1.2 \mathrm{~m}$; adopting a specific weight of 2.20 $\mathrm{g} / \mathrm{m}^{3}$, the mega-clast volume ranges from about 2 to 30 tons (Table 1). The biggest boulder is at $27 \mathrm{~m}$ inland at about $5 \mathrm{~m}$ above b.s.l.

The $a$-axis of the bigger part of the boulders are E-W oriented, whereas other show a like N-S orientation (Fig. 6).

Most of the boulders have been carved out from an area close to the supratidal zone, as can be ascertained from the presence on its surfaces of wide, flat rock pools and sparse dead barnacles in an area where, at present, they don't live. Often these boulders are overturned or in an unstable position (Fig. 7); due to the tilting, original rock pools have been subsequently shaped by new horizontal solution pools formed because of karstic processes.

Moreover, some boulders clearly indicate their sublitoral origin since they are characterised by the presence of biogenic encrustations of Vermetid $s p$. These well-preserved bioconcretions indicate a very recent age of formation and limited reworking during their transport from the sublitoral to the adlitoral zone (Fig. 8); in fact, in the case of multiphase transport or a long permanence in subaerial environments they should have been destroyed or damaged in the very least.

On the sea-ward side of the berm, the bedrock is marked by erosional s-forms (Fig. 9), about 30-35 $\mathrm{m}$ from the coastline; they bound the base of the first step of the promontory at about $3 \mathrm{~m}$ (a.s.1.). The s-forms bring to mind "sichelwannen" that are smooth and polished surfaces, engraved by a high energy plastic flow where rocky surfaces are not very resistant (Bryant and Young, 1996; Bryant, 2001 and references therein). Moreover, at meso-scale, the presence of an undulated and smooth soil-less surface, extending from the coastline to the top of the step where boul- 
Table 1. Features of more representative boulders from Punta Saguerra; they have been chosen in function of their weight, $a$-axis orientation, elevation and distance from the coastline. The last two columns contain the calculated minimum heights of the storm wave and of the tsunami necessary to move boulders inland. The heights were obtained by applying the Pignatelli et al. (2009) equation starting from the boulder sizes.

\begin{tabular}{|c|c|c|c|c|c|c|c|}
\hline $\begin{array}{c}\text { Saguerra } \\
\text { Cape }\end{array}$ & ID & $\begin{array}{c}a \text {-axis } \\
(\mathrm{m})\end{array}$ & $\begin{array}{c}b \text {-axis } \\
(\mathrm{m})\end{array}$ & $\begin{array}{c}c \text {-axis } \\
(\mathrm{m})\end{array}$ & $\begin{array}{c}\text { Weight } \\
\text { (t) }\end{array}$ & $\begin{array}{l}\text { Storm wave } \\
\text { height }(\mathrm{m})\end{array}$ & $\begin{array}{c}\text { Tsunami } \\
\text { height }(\mathrm{m})\end{array}$ \\
\hline \multirow{8}{*}{$\varrho_{\mathrm{s}}=2.2 \mathrm{~g} / \mathrm{cm}^{3}$} & BA01 & 3.00 & 1.10 & 0.70 & 4.97 & 9.44 & 2.36 \\
\hline & BA02 & 4.10 & 3.30 & 0.90 & 26.18 & 12.13 & 3.03 \\
\hline & BA04 & 3.30 & 1.63 & 0.87 & 10.06 & 11.73 & 2.93 \\
\hline & BA16 & 3.40 & 1.60 & 1.07 & 12.52 & 14.43 & 3.61 \\
\hline & BA35 & 3.70 & 3.10 & 1.20 & 29.59 & 16.18 & 4.04 \\
\hline & BA43 & 1.20 & 1.12 & 0.60 & 1.73 & 8.09 & 2.02 \\
\hline & BA55 & 0.90 & 0.64 & 0.65 & 0.74 & 8.76 & 2.19 \\
\hline & BA72 & 1.36 & 1.10 & 0.26 & 0.84 & 3.51 & 0.88 \\
\hline
\end{tabular}

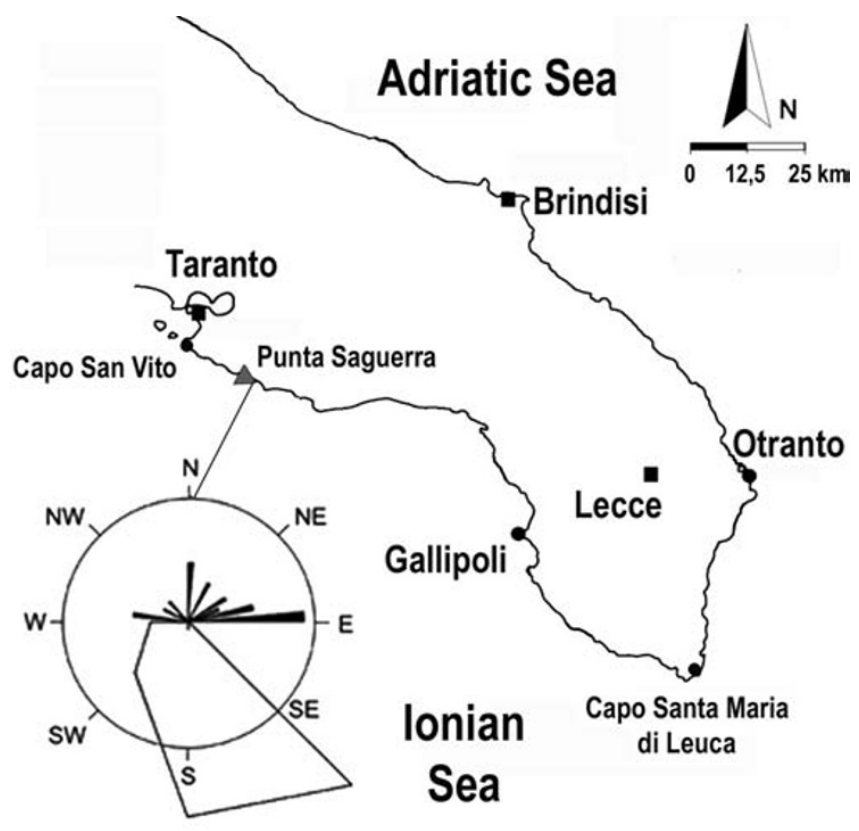

Fig. 6. $a$-axis orientation of boulders at Punta Saguerra compared to the direction of the approaching storm-generated waves.

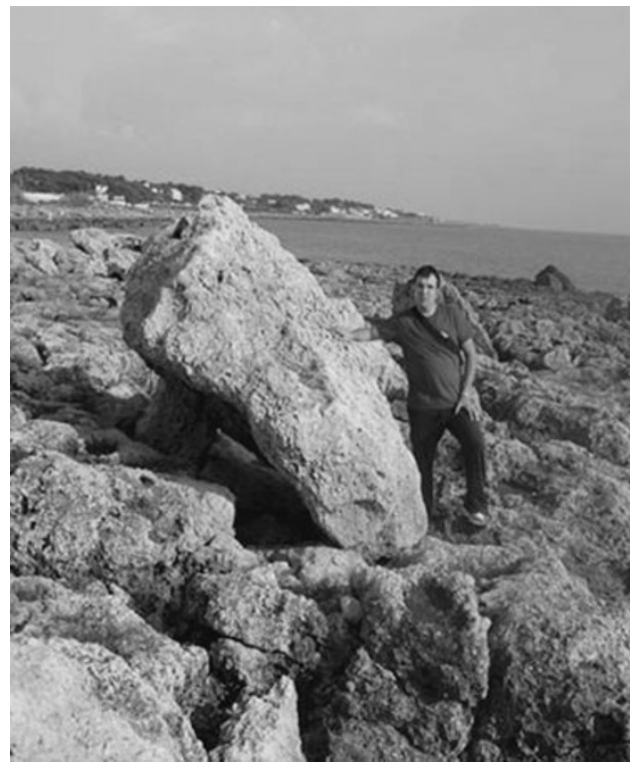

Fig. 7. A boulder in evident unstable equilibrium in the centre of the berm. der deposits are arranged, could be considered significant evidence of a tsunami impact (Kelletat and Schellmann, 2002; Whelan and Kelletat, 2003).

ìì-The third zone is a steeper terrace placed between 6 and $11 \mathrm{~m}$ a.b.s.l.; its external area is marked with discontinuous vegetative cover while the inner area is covered by soil with continuous halophyte vegetation.

\subsection{Digital surveys}

A combined Differential GPS and Terrestrial Laser Scanner survey was performed in order to obtain the position of each boulder and to define the coastal morphography and the detailed microtopography (Fig. 5). This kind of survey permit also to define boulder volumes, imbrication, $a$-axis azimuth (Table 1) and to hypothesize their pretransport position (Pignatelli et al., 2010; Mastronuzzi and Pignatelli, 2011). Digital survey were performed using a Leica Scanstation 2 able to scan the landscape up to about $300 \mathrm{~m}$ from the laser-beam generator in function of the reflectivity of the scanned object (Fig. 10); the instruments captures up to a maximum of 50,000 points per second.

The $3 \mathrm{D}$ view of the landscape derive by the combination of some scansions overlapped in a post processing phase us- 

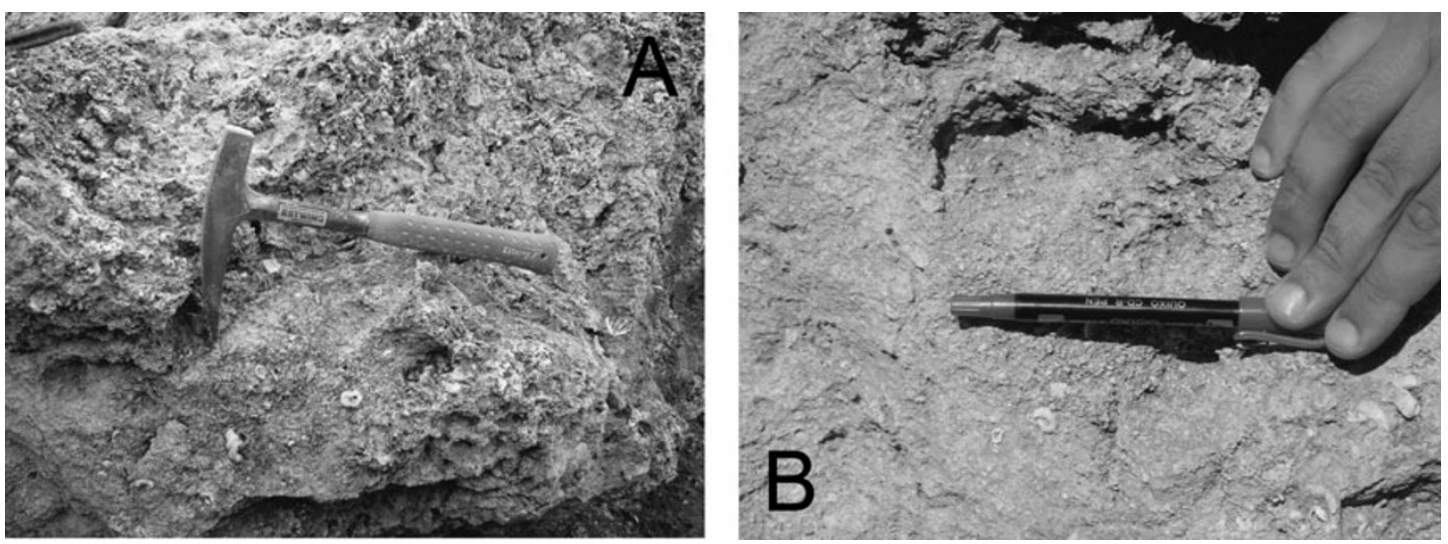

Fig. 8. Bioconcretion of Vermetids sp; two samples were collected on boulders B31 (A) and one on boulder B33 (B).

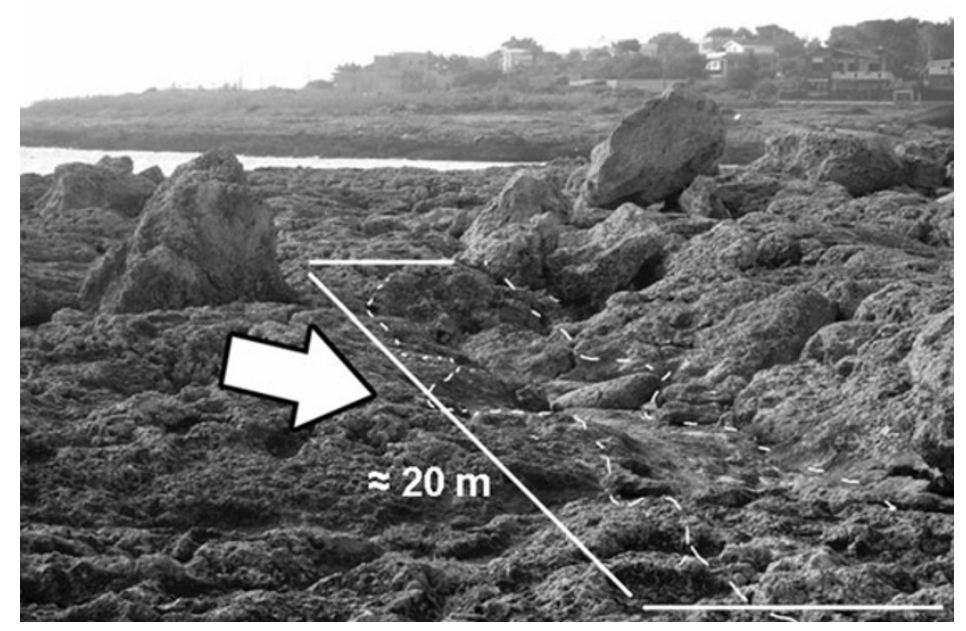

Fig. 9. S-form similar to "sichelwanne", at the foot of the berm.

ing Cyclone 6.03 software, that produce a unique 3D Modelspace. This is possible since at least five targets are positioned to be captured by at least three scansions; the position of each of them were surveyed with a GPS Leica 1230 in differential modality in Real Time Kinematic (RTK) synchronization, using the Global Navigation Satellite System (GNSS) of Apulia region.

\subsection{Age determinations}

Three vermetid samples were collected from the surface of two different imbricated and overturned boulders (B31, B33) of the berm, each weighing about 5 and 7 tons (Fig. 8(A, B)); the well-preserved state of the bioconcretions seems to exclude any transport on the emerged surface in a time different from that of the detachment from the sublittoral zone; moreover, it seems unlikely that they were exposed to meteorological activity for a long period of time, again, because of their well-preserved state. Their age has been established by means of AMS age determinations in the CEDAD Laboratory of the University of Lecce. The calibrate ages resulting from radiometric determination are very recent: the conventional ${ }^{14} \mathrm{C}$ ages of the samples are respectively $413 \pm 40 \mathrm{BP}, 489 \pm 50 \mathrm{BP}$ and $426 \pm 35 \mathrm{BP}$. The results of the AMS analyses have been calibrated by using the CALIB 6.0 software (Stuiver and Reimer, 2010) and adopting a delta $R$ value of $121 \pm 60$. Having taken

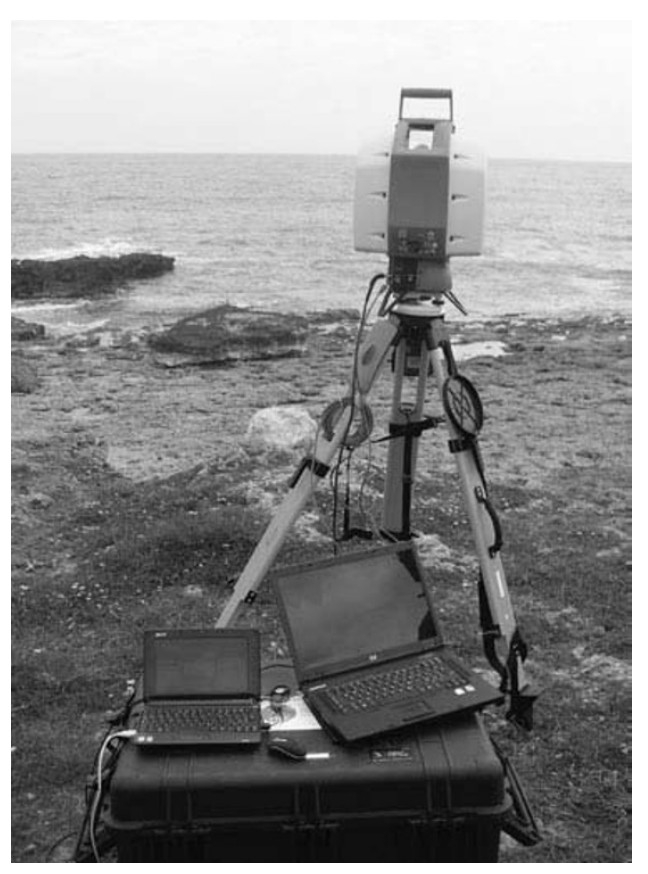

Fig. 10. The terrestrial laser scanner (TLS) Leica Scan Station 2 at work. 
Table 2. AMS radiocarbon age determinations of some samples collected at Punta Saguerra. The calibrated ages were obtained by using Calib 6.0 software (Stuiver and Reimer, 2010).

\begin{tabular}{|c|c|c|c|c|c|c|c|c|c|}
\hline ID Sample & Boulder & Description & $\delta^{13} \mathrm{C}$ & $\begin{array}{c}\text { Radiocarbon } \\
\text { age }\end{array}$ & $\begin{array}{c}\text { Age } \\
\text { uncertainty }\end{array}$ & $\Delta R$ & $\begin{array}{c}\text { Calibrated } \\
\text { age }\end{array}$ & $1 \sigma$ & $2 \sigma$ \\
\hline $\begin{array}{c}\text { Baia } \\
\text { d'Argento }\end{array}$ & B31 & Vermetids & $0.5 \%$ & 413 & $\pm 40{ }^{14} \mathrm{C}$ & $121 \pm 60$ & $\begin{array}{l}1889 \text { AD: } \\
1947 \text { AD }\end{array}$ & 0.11 & \\
\hline LTL1178A & & & & & & $121 \pm 60$ & $\begin{array}{l}1813 \text { AD: } \\
1955 \text { AD }\end{array}$ & & 1 \\
\hline $\begin{array}{c}\text { Baia } \\
\text { d'Argento }\end{array}$ & B31 & Vermetids & $1.3 \%$ & 489 & $\pm 60{ }^{14} \mathrm{C}$ & $121 \pm 60$ & $\begin{array}{l}1853 \text { AD: } \\
1952 \text { AD }\end{array}$ & 1 & \\
\hline \multirow[t]{2}{*}{ LTL1179A } & & & & & & $121 \pm 60$ & $\begin{array}{l}1801 \text { AD: } \\
1953 \text { AD }\end{array}$ & & 0.064 \\
\hline & & & & & & $121 \pm 60$ & $\begin{array}{l}1702 \text { AD: } \\
1951 \text { AD }\end{array}$ & & 0.904 \\
\hline $\begin{array}{c}\text { Baia } \\
\text { d'Argento }\end{array}$ & B33 & Vermetids & $0.4 \%$ & 426 & $\pm 35{ }^{14} \mathrm{C}$ & $121 \pm 60$ & $\begin{array}{l}1888 \text { AD: } \\
1954 \text { AD }\end{array}$ & 1 & \\
\hline LTL2209A & & & & & & $121 \pm 60$ & $\begin{array}{l}1811 \text { AD: } \\
1954 \text { AD }\end{array}$ & & 1 \\
\hline
\end{tabular}

into account a confidence interval of $2 \sigma$, the obtained ages span intervals of [1801-1951 AD], [1702-1951 AD] and [1813-1951 AD] (Table 2). The results indicate that the samples have a very recent age; their deposition would have occurred about two centuries ago. Unfortunately, radiocarbon analyses of recent marine samples do not allow us to obtain very precise age determinations within a limited error bar. Especially when adopting the calibration method, the biggest security in the age determination $(2 \sigma)$ corresponds to the largest gaussian curve which would imply an enormous error bar not useful on its own, when aiming to identify the precise time of the event.

\section{Meteorological Settings}

The Ionian Basin is exposed to strong winds generated by the seasonal prevalence of Siberian and Azores anticyclones. Respectively, they generate winds with directions mainly from the N-NE or S-SE. In the case of N-NE Siberian winds, a fetch is limited by the protective Southern Appennines; during the S-SE Azores winds, a fetch can extend up to about 700 nautical miles from the Gulf of Sidra (Libya). Data recorded by RON (Rete Ondametrica Nazionale) buoys, (Corsini et al., 2002) have been available since 1989. Wave data in the northern Ionian Sea are recorded by the Crotone buoy located in the northern Ionian Sea at the southernmost limit of the Taranto Gulf (Fig. 11). The integration of RON data with Italian Navy wave-wind data covering the last 60 years allows the frequency of sea storms to be reconstructed (Istituto Idrografico della Marina, 1982). Storm frequency records during these years show that wind speeds between 15 and 20 knots have been decreasing in the central area of the Mediterranean Sea. However, sea storms have been increasing due to wind speeds between 11 and 14 knots and wind speeds exceeding 27 knots along the Ionian coasts.

The meteorological stations placed along the coast of the Gulf of Taranto-Capo Colonne near Crotone and Capo San Vito near Taranto-indicate that the main sea storms come from the N-NE and the S-SE: the first station shows that gales occur especially in winter and have an average duration of approximately 40 hours; the latter station primarily measuring sea storms concentrated in the month of January, register a S-SSE wind direction with a duration of approximately 35 hours. The meteorological station located in southern Apulia (Capo Santa Maria di Leuca) registered important sea storms coming from the S-SW in October and January with the most limited fetch sector and a duration of approximately 28 hours.

An evaluation of RON records from the Crotone buoys, with regard to annual extreme offshore waves covering the time period between 01/07/1989 and 31/12/2001 (Arena, 1999) has been carried out. A 6.2-meter-high extreme wave from the SE, the biggest registered, was recorded in February 1994. The return times of this offshore wave have been evaluated using the Gümbel distribution. For a return time of 50 years, offshore waves recorded by the Crotone buoy can reach peaks approximately $1.3 \%$ higher than the maximum wave height recorded (Fig. 11).

\section{Discussion}

The boulders that constitute the Punta Saguerra berm weigh up to 30 tons and are placed at a distance between 25 and $45 \mathrm{~m}$ from the coastline. The disarticulation of the boulders and their transport inland have been possible due to the presence of a network of horizontal (transgression surface on the local basement and stratification in the calcarenite) and vertical (fractures) discontinuities in the calcarenite body, well evident all along the coastline both in sub-aerial and submerged parts of the cliff. These features seem to indicate the "joint bounded boulders" scenario described by Nott (1997, 2003) (Fig. 12).

The boulder spatial distribution seems to indicate a substantial correspondence between the $a$-axis orientation and the direction of the main storms. An important part of the boulders has its main axis E-W and NE-SW oriented, so orthogonal to the approaching direction of the main waves coming from $\mathrm{S}$ or $\mathrm{SE}$; on the other hand, many boulders have their $a$-axis NW-SE or N-S oriented (Fig. 6). The correspondence between $a$-axis orientation and the approaching direction of main wave is only apparent; in fact, since 


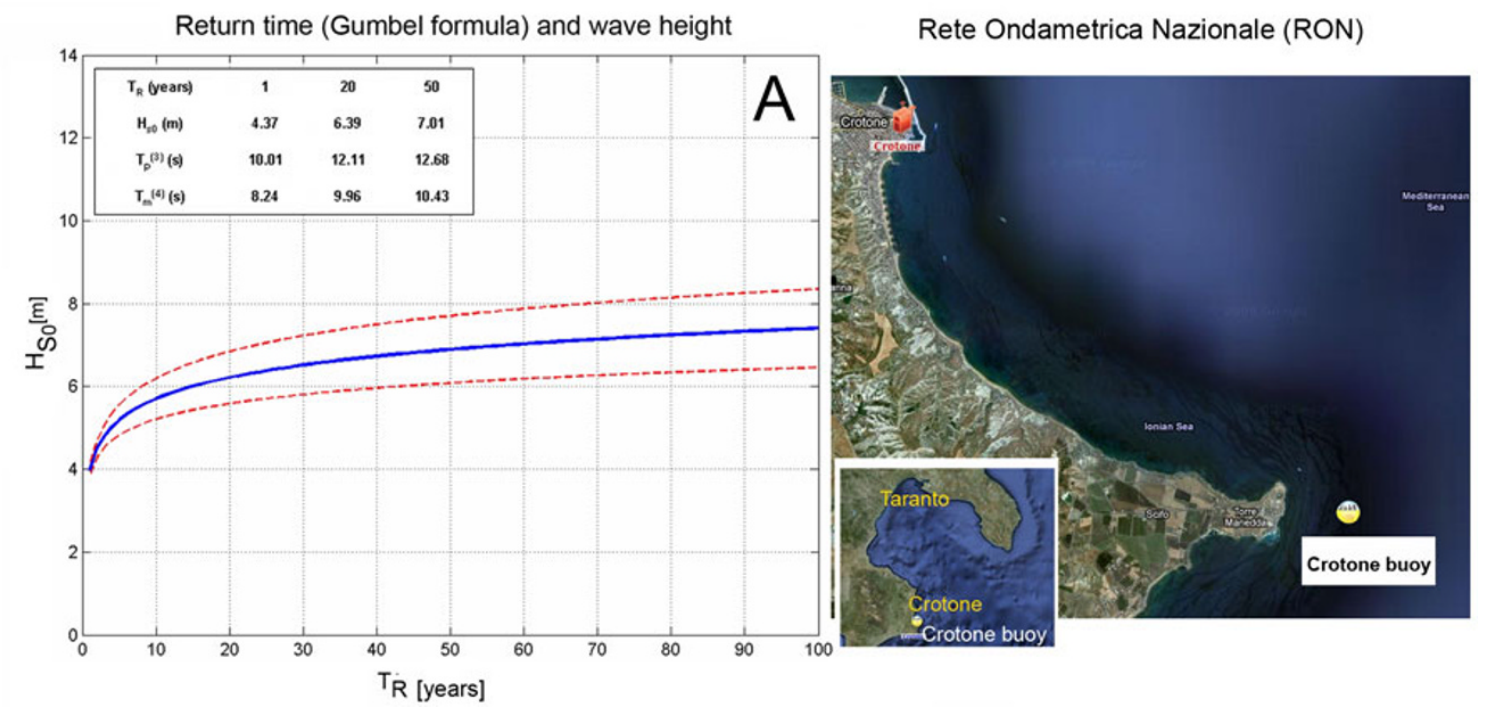

Fig. 11. Data from the Crotone buoy and its position.

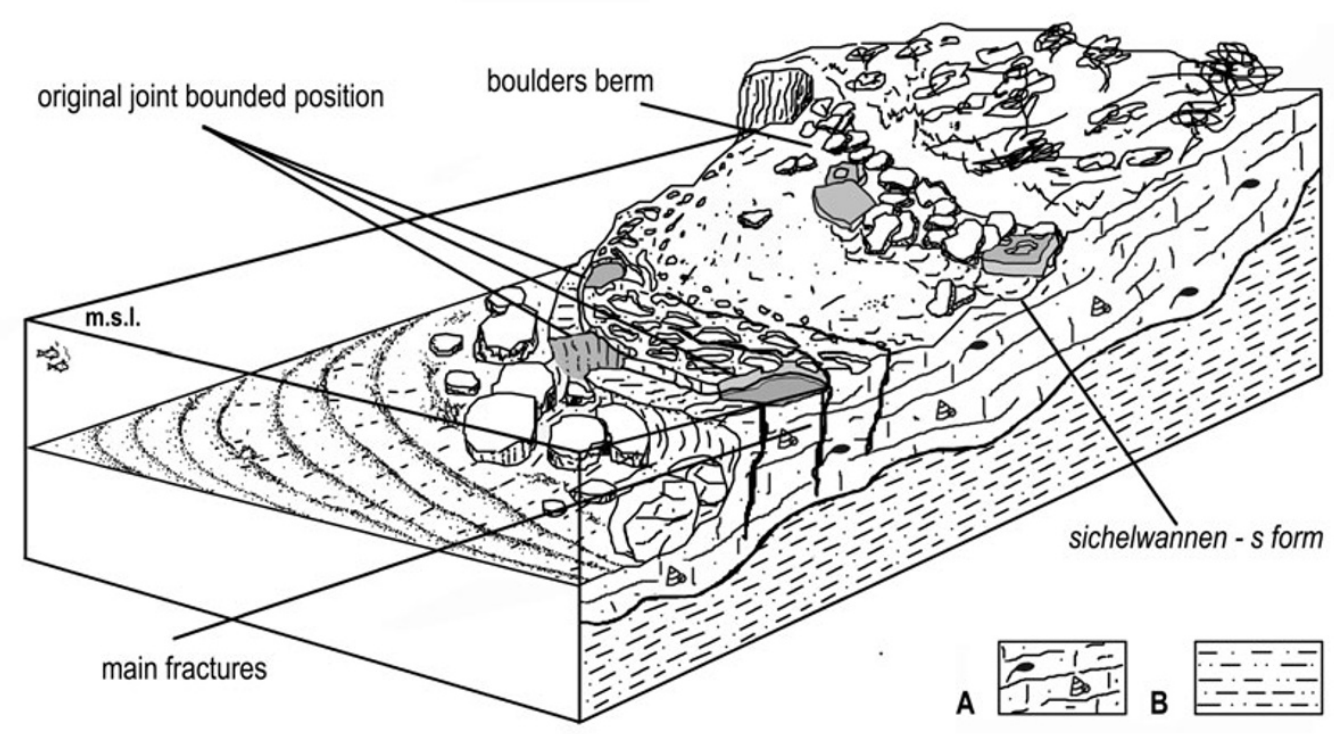

Fig. 12. Block diagram of Punta Saguerra; in grey the original position of some boulders in joint bounded scenario and their present positions. (A-Upper Pleistocene algal calcarenite; B-Plio Pleistocene silty clay).

their physical features, these last were refracted due its interaction with the continental shelf and hit the coast from SW (Mastronuzzi and Sansò, 1998).

Starting from the hydrodynamic equations suggested by Pignatelli et al. (2009) for tsunami and storm wave approaches, and applying these formulas to the biggest boulder recognizable in the ridge, it is possible to characterize the minimum wave able to move it landward (Table 1). Accordingly, to initiate the transport of a 30-ton boulder, about polyhedric in shape and characterised by a $c$-axis of $1.20 \mathrm{~m}$, a minimum storm wave of about $16.18 \mathrm{~m}$ high or a tsunami of about $4.04 \mathrm{~m}$ high was necessary. A storm wave with such characteristics is very unlikely in the Gulf of Taranto. In fact, here, the Crotone buoy, activated by RON and RMN (Rete Mareografica Nazionale), has indicated the maximum storm wave recorded in deep sea to be $6.2 \mathrm{~m}$ high. Moreover, by applying the Gumbel treatment to available recorded data (from 1989 to 2001), a return time of 50 years for a maximum wave height of $7.01 \mathrm{~m}$ is obtained (Fig. 9). Important indications come from the analysis of the bathymetry just in front of the promontory-about $-5 \mathrm{~m}$ - and of the bottom slope. Experimental studies have demonstrated that waves break at different distances from the coastline in function of the ratio between the impacting wave height $\left(H_{\mathrm{b}}\right)$ and the water depth $\left(W_{\mathrm{d}}\right)$; this ratio is an estimated average of $0.71-0.78$ (Keulegan and Patterson, 
Table 3. Tsunami events generated in the Taranto Gulf and in the nearby Ionian Sea in the 1801-1951 period (from CPTI, 2004; Tinti et al., 2004).

\begin{tabular}{|c|c|c|c|c|c|c|c|}
\hline \multirow[t]{3}{*}{ Day } & \multirow[t]{3}{*}{ Year } & \multirow[t]{3}{*}{ Zone } & \multirow[t]{3}{*}{ Localities } & \multicolumn{2}{|c|}{ Geographycal } & \multirow{2}{*}{$\begin{array}{c}\text { Earthquake } \\
\text { Intensity }\end{array}$} & \multirow{2}{*}{$\begin{array}{c}\text { Tsunami } \\
\text { intensity }\end{array}$} \\
\hline & & & & \multicolumn{2}{|c|}{ Coordinates } & & \\
\hline & & & & Lat & Long & (Mercalli scale) & \\
\hline 8 March & 1832 & Ionian Calabria & Crotone & 39 & 17 & 10 & 3 \\
\hline \multirow[t]{5}{*}{24 April } & \multirow[t]{5}{*}{1836} & \multirow[t]{5}{*}{ Ionian Calabria } & Crosia, Marina di S., & 36.6 & \multirow[t]{5}{*}{16.6} & \multirow[t]{5}{*}{9} & \multirow[t]{5}{*}{4} \\
\hline & & & Angelo, & & & & \\
\hline & & & Cropalati, Corigliano, & & & & \\
\hline & & & \multicolumn{2}{|c|}{ Calopezzati Marina, Rossano, } & & & \\
\hline & & & Golfo di Taranto & & & & \\
\hline 23 October & 1907 & Ionian Calabria & Capo Bruzzano & 38.15 & 16 & 8.5 & 3 \\
\hline
\end{tabular}

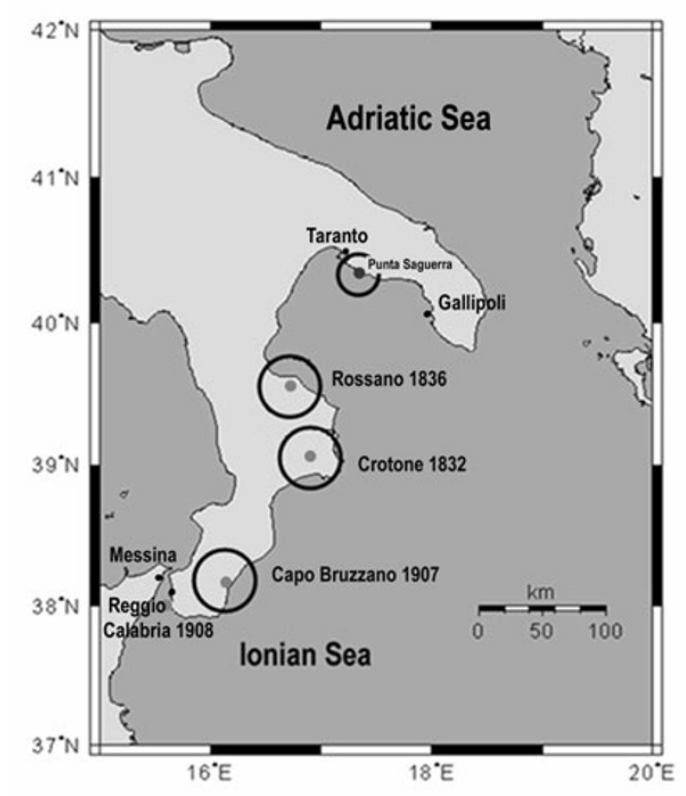

Fig. 13. Localisation of the epicentres of the Messina and Reggio Calabria (1908), Capo Bruzzano (1907), Rossano (1836) and Crotone (1832) earthquakes; the smallest circle indicates Punta Saguerra.

1940 ) in the case of a generic bottom. Experimental data indicate a value of approximately $0.44-0.6$ for a horizontal bottom or, in the case of a steeper bottom, 0.78-1.03 (Massel, 1997; Galvin, 1972). Therefore, considering that the sea bottom in front of Punta Saguerra is characterised by a mean slope of about $6 \%$, it is necessary to apply the first ratio of $0.71-0.78$; a storm wave of about $16.18 \mathrm{~m}$ high has the breaking point at a water depth of about $21-23 \mathrm{~m}$, thus $350-400 \mathrm{~m}$ from the coastline. Due to this distance, it would be difficult to affirm that the broken wave responsible for the detachment and transport of a 30-tons boulder could be this sea storm wave, never registered in this area. Moreover, a normal wave, like those registered by RON, collapse at a $W_{\mathrm{d}}=9-10 \mathrm{~m}$, about $60-70 \mathrm{~m}$ from the coastline. Along this tract, its energy is influenced by the roughness of the sea-bottom dissipating by the time it reaches the coastline, unable to scatter 30 -tons boulders $30 \mathrm{~m}$ inland. Besides, the distribution of some boulders along the $a$-axis azimuth of the Punta Saguerra berm correspond to the approaching directions of the wave trains generated by known sea storms (Fig. 6); this seems to indicate a mixed depositional origin (sea-storm and tsunami) of the boulders, but this can only be considered reliable for boulders whose weights are lower than 1.5-2.5 tons (Mastronuzzi et al., 2006). It should be noted that some strong storms have occurred in the last five years. They are considered to be among the strongest to have ever occurred but never characterised by waves higher than $6 \mathrm{~m}$ (www.idromare.it); the connected waves moved boulders that were never heavier than 1.0 tons and only transported to the supratidal area. Therefore, more probable is the height of $4.04 \mathrm{~m}$ that was estimated using the morphological features of the biggest boulder for the possible impacting tsunami; it justifies the detachment, the transport and the accumulation of an entire ridge at about $35 \mathrm{~m}$ from the coastline. In fact considering an impacting tsunami about $4 \mathrm{~m}$ high, and applying the Pigantelli et al. (2009) formula, the maximum inland flooding is comparable to the trimline extension. Presently, the surface at Punta Saguerra is smooth and without soil or vegetation; this could be attributed to a wave impact having caused the erosion of a previously soil. The presence of erosional forms is an indication of a huge wave that impacted the coast promontory with a high-energy flow; these types of forms have been observed and attributed to the effect of tsunamis because of their flooding plastic flow (water + debris) that could shape the bedrock even at a distance from the coastline.

The results of the AMS age determination are in agreement among themselves (Table 2). The first two ages overlap, while the third one shows a little difference compensated by a major error bar. In substance they are very similar and the calibrated ages seem to indicate that one-or more (!?) — catastrophic events occurred in the time spanning from 1801 and 1951. Unfortunately, AMS age determination is more limited with regard to marine shells from more recent times. Data that could confirm radiocarbon ages derive from the Catalogo Parametrico dei Terremoti Italiani (Gruppo di Lavoro CPTI, 2004) and the tsunami catalogue (Tinti et al., 2004). Three strong tsunami-generative earthquakes occurred in the span of time individuated by the ${ }^{14} \mathrm{C}$ age determinations: on March 8,1832 in the Crotone area (Central Calabria), on April 24, 1836 along the coast of Rossano Calabro (northern Calabria) and on October 23, 1907 in southern Calabria (Table 3) (Fig. 13). On December 
28, 1908, another strong earthquake generated the tsunami that destroyed the coastal areas of Messina and Reggio Calabria killing a thousand people; but here are no historical documents that testify the propagation of this wave reaching the inner part of the Gulf of Taranto.

On the contrary, the impact of the Rossano Calabro earthquake is well-documented along the coast of Calabria; in particular eyewitness accounts clearly indicate that the tsunami flooding the Rossano coastal area arrived 80 steeps inland, corresponding to about $70 \mathrm{~m}$ (Romano, 1836; Rossi, 1836, 1837; De Rosis, 1838). De Rosis (1838) reports the words of the chief fishermen Antonio Florio from Amalfi: “... verso le ore sei (a.m., April, 24) mi recai colla ciurma al mio seguito sulla spiaggia ... fummo improvvisamente scossi da forte tremuoto ... in questo mentre il mare si allontanò di molti passi e continuando la terra a muoversi, ci affrettammo tutti sbigottiti di ritornare al pagliaro, ove giunti tutti attoniti osservammo che il mare, spinto da fiera tempesta, alzò le sue onde con tanta veemenza che giunsero sino al pagliaro: nel ritirarsi portò seco sette nostre barche, facendole urtare tra di loro in modo che rimasero danneggiate: continuò la forte agitazione del mare per più tempo, indi gradatamente si ritirò alla sua sponda, ma sempre fremente, per cui non andammo alla pesca neppure il di seguente: la mattina ritrovammo nel litorale sbalzati dal mare molti pesci ..." (“... around 6 am, April 24, $I$ reached the shore with my crew ... we suddenly felt a tremor of a strong earthquake... while the sea withdrew several steps, the land continued to move. Startled, we rushed toward the haystack, we watched in astonishment as the proud tempest instigated the rising of waves with such vehemence that they reached the haystack. As the sea withdrew, it took with it seven of our boats, hurtling them against one another so much so as to damage them. The turbulence continued for a while, then gradually the sea withdrew to its bottom; still quivering, we did not even go fishing the next day. The next morning we found fishes strewn along the coast...").

Moreover, the same witness indicates changes also in sea bathymetry as suggested by the impossibility to use the sciabaca, a fishing instrument: “... tentammo di buttare la sciabaca nel solito luogo, ma con sorpresa scoprimmo, che quel tratto di fondo di mare, ove abbiamo fatto sempre la pesca, e da noi per tanti anni scandagliata la profondità di venti passi d'acqua, si è talmente inalzata con monti di Duna, Cotone o siano Albajone, che in oggi non se ne misurano che quattro ...". ("... we attempted to throw the sciabaca in the waters where we always fished, but surprisingly, we discovered that the sea bottom, that previously had had a depth of 20 steps had now shallowed to 4 steps due to mounts of Dune, Cotone or Albajone ...). Considering the present geomorphological features of the Rossano coast, marked by the presence of a pebble beach that continues below the sea level 5-10 m, it is reasonable to hypothesize that the back-wash flow accumulated a large quantity of sediment in the submerged beach, generating an extended submerged bar. Another description reported by De Rosis is that from the chief fisherman Antonio Apicella from Majuri: "La sera del 24 aprile il mare si ritrovava in bonaccia, talchè lasciai le mie barche tirate a poca distanza dal lido.
Verso le due della notte, che colla mia ciurma riposavamo nel pagliaio, due marinai ch'erano ancora all'erta, vennero ad avvertirmi di avere inteso un rombo, e d'essere infocata l'aria dal lato di levante, chiedendomi se volevo, che le barche fossero tirate più in giù, ma siccome mi dissero, che non vi era vento ed il mare in calma, gli risposi d'essere inutile tal fatica, mentre da li a poche ore saremmo andati a pesca. Presi tutti dal sonno, fummo risvegliati da un forte scotimento della terra, che per il moto di compressione si alzava, or si abbassava da i nostri piedi: intesi che l'onde frangevano, e nell' atto che la terra tremava corsi di unito alla ciurma verso le barche per salvarle, ma non potei tanto eseguire perché il mare l'aveva poste a galla: in questo mentre mi si abbassò il suolo, ed il mare mi giunse sino al petto sollevandomi con impeto, talchè fui obbligato di unità a molti miei marinai di porci a nuoto e fummo slanciati dal mare sino alla pagliaia, distante dal lido più di ottanta passi..." ("On the evening of April 24, the sea was dead calm, so much so that I left my boats tied close to the shore. Around 2 am, while my crew and I rested in the haystack, two sailors who had been keeping watch came to give notice of a rumble they had heard and that the air to the east had turned fiery. They asked me if I wanted to pull the boats in. But since they said there was no wind and that the sea was calm, I told them to save the hassle and that, in a few hours we'd be heading out to fish. Having then fallen deep asleep, we were woken by a strong shaking of the ground and for the motion of the earth's compression, the ground started to rise and fall below our feet. Understanding now that the waves were crashing and the earth quaking, we ran toward the boats to save them but to no avail, for the sea had taken them afloat. Meanwhile, the ground beneath me lowered and the sea reached my chest raising me impetuously. I was obliged to unite with most of my sailors and took to swimming, we were hurled from the sea to the haystacks for a distance of 80 steps.").

Unfortunately, the event is not as well-documented on the eastern coast of Ionian sea as it is on the western coast. The only available testimoniance is found in the chronicle written by Baffi (1929), almost a century later: “... dopo una primavera molto piovosa ed un'orribile tempesta accaduta il 17 aprile 1836 nel golfo tarentino seguirono pochi giorni sereni fino al 24 Aprile 1836 ... Verso mezzanotte dell' istesso giorno gli animali mostrarono soverchia inquietudine, il mare divenne grosso e tempestoso e sopra di esso fa' vista una meteora di color fuoco, in quel punto accompagnato da cupo rumore un terremoto durò $20 \mathrm{sec}$ ondi e dopo 3 minuti replicò violentemente ..." ("... after a wet spring season, and a terrible tempest on April 17, 1836, a few calm days followed in the Gulf of Taranto, but only til April 24. ... Around midnight of that day, the animals began to show excessive inquietude. The sea grew big and tempestuous and above it, the sky had a fiery glow, then came a dark noise and a quake lasting 20 seconds. Three minutes later another violent tremor followed ..."). In comparison to the eyewitness reports presented in the local chronicles, it seems that those of Baffi (1929) have been derived and not true to the descriptions given by the local inhabitants. Therefore, there is no direct testimony that can prove the impact of the 1836 tsunami on the Ionian Apu- 
lia. On the other hand, to distinguish between the 1836 and the 1832 events, effectively very close in the time, is quite hard. The calibrated ${ }^{14} \mathrm{C}$ age yielded by the AMS analyses has a range much too extended to allow us to distinguish between the two events in a large gaussian distribution. In effect, if the directions of both approaching waves are reconstructed to come from the WSW-ESE and both epicentres of the earthquakes are placed ESE of Punta Saguerra, it is true that the localisation of the 1832 epicentre with respect to the Punta Saguerra locality is protected by the Crotone peninsula (Fig. 13) and more distant than the 1836 event. These considerations would also exclude the possibility that the tsunami that hit Punta Saguerra was generated by the Capo Bruzzano earthquake. Finally, the 1836 tsunami was stronger (measuring 4 on the tsunami intensity scale) than the 1832 and 1907 ones ( 3 on the tsunami intensity scale).

Recent seismic registration performed by the seismic observatory at the University "Aldo Moro" in Bari evidenced moderate seismic activity with an epicentre in the sea bottom not far from the Salento coast-like the sequence that occurred near Gallipoli on May 7, $1983(M=5.3)$ and along the coast of Calabria-like that of April 17, 2002 near Rossano ( $M=4.7)$ (Fig. 2(B)).

\section{Conclusions}

By comparing all the data gathered from geomorphological, topographic and geochronological surveys completed by hydrodynamics considerations and historical chronicles, it is possible to obtain important conclusions about the boulders recognised in Punta Saguerra. The Punta Saguerra berm is composed of some tens of mega-boulders weighing up to 30 tons. Generally, the boulders come from the adlittoral/infralittoral/sublittoral zones. The presence of the boulders is associated with the presence of trimline and sichelwanne $-s$ forms. The size of the boulders and other morphological features seem compatible with a possible impact from one or more tsunamis, since the impact of a storm normally occurring in this area, however exceptional, would have been less energetic and thus unable to scatter boulders inland from the sublittoral zone. Some of them preserve biological concrections whose age has been obtained from AMS analyses. Unfortunately, the results from the analyses do not offer a clear distinction between the two seismic-generated tsunami events of 1832 and 1836, having occurred so close in time. Based on the available chronicles, the events responsible for the formation of the berm can easily be attributed to the impact of a tsunami able to flood the Rossano coast and suggests the impact of an exceptional wave along the Ionian coast of Apulia.

Reassuming and considering all the data available, it is more possible that the boulder ridge was put in place by only one tsunami event generated by the earthquakes occurring on April 24, 1836 near Rossano in Calabria. It is also possible that this strong event erased pre-existent evidence correlated to the 1832 earthquake. The final conclusion regards the erosional forms: phenomena of trimline generation are well evident at the base of the ridge where rounded smooth-surfaces deriving from covered karstic phenomena are recognisable. Unfortunately, it is not possible to evaluate if the stripping can be correlated to the 1832 , or less probably to the 1907 event, or whether it was due to the more energetic 1836 event. The presence of s-shaped forms indicate that the event responsible for all these erosional landforms was quite energetic and, so, the attribution of the biggest feature of the present Punta Saguerra landscape to the April 24, 1836 tsunami is realistic.

Acknowledgments. The authors sincerely thank Dr. Osamu Fujiwara and the other anonymous reviewer for helpful corrections and valuable comments on the manuscript. We would also like to thank Dr. Ladan Doroudian for the improvement of the English form. This research has been financially supported by the Project S1 2007/09 "Analysis of the seismic potential in Italy for the evaluation of the seismic hazard" dell'Istituto Nazionale di Geofisica e Vulcanologia-Dipartimento Protezione Civile (Responsabili del Progetto: Salvatore Barba, Carlo Doglioni; Resp. UOL Bari Prof. G. Mastronuzzi) and by Research Project Bari University 2009 "Modellizzazione e valutazione del rischio costiero da eventi parossistici" (Resp. Prof. G. Mastronuzzi). The authors would like to thank Prof. Paolo Sansò, Università del Salento, Lecce, Italy, for the useful discussions. The paper is an Italian contribution to IGCP Project n ${ }^{\circ} 495$ "Quaternary Land-Ocean Interactions: Driving Mechanisms and Coastal Responses". (Project Leaders: Dr. A. Long, University of Durham, UK, and Dr. S. Islam, University of Chittangong, Bangladesh).

\section{References}

Arena, F., Il rischio ondoso nei mari italiani, Edizioni BIOS, 136 pp., Cosenza, 1999 (in Italian)

Auriemma, R., G. Mastronuzzi, and P. Sansò, Relative sea-level changes during the Holocene along the Coast of Southern Apulia (Italia), Géomorphologie, 1, 19-34, 2004.

Baffi, E., Saggio di effemeridi tarantine, Bollettino della Provincia Ionica (Taras), IV, 1-2, 47-61, 1929 (in Italian).

Barbano, M. S., C. Pirrotta, and F. Gerardi, Large boulders along the southeastern Ionian coast of Sicily: Storm or tsunami deposits?, Mar. Geol., 275(14), 140-154, 2010.

Belluomini, G., M. Caldara, C. Casini, M. Cerasoli, L. Manfra, G. Mastronuzzi, G. Palmentola, P. Sansò, P. Tuccimei, and P. L. Vesica, The age of Late Pleistocene shorelines and tectonic activity of Taranto area, Southern Italy, Quat. Sci. Rev., 21, 525-547, 2002.

Bryant, E. and R. Young, Bedrock-sculpturing by tsunami, south coast New South Wales, J. Geol., 104, 565-582, 1996.

Bryant, E. A., Tsunami. The Underrated Hazard, 320 pp, Cambridge University Press, Cambridge, U.K., 2001.

Butler, R. W. H., S. Mazzoli, S. Corrado, M. De Donatis, D. Scrocca, D. Di Bucci, R. Gambini, G. Naso, C. Nicolai, P. Shiner, and V. Zucconi, Applying thickskinned tectonic models to the Apennine thrust belt of Italy-Limitations and implications, in Thrust Tectonics and Hydrocarbon Systems, edited by K. McClay, 647-667, American Association of Petroleum Geologists Memoir, 82 pp., 2004.

Chiarabba, C., L. Jovane, and R. Di Stefano, A new view of Italian seismicity using 20 years of instrumental recordings, Tectonophysics, $\mathbf{3 9 5}$, 251-268, 2005

Cita, M. B. and G. Aloisi, Deep-sea tsunami deposits triggered by the explosion of Santorini (3500 y BP), eastern Mediterranean, Sediment. Geol., 135, 181-203, 2000.

Colizza, E., N. Corradi, A. Cuppari, F. Fanucci, D. Morelli, and A. Del Ben, Rischi geologici ed ambientali sul margine continentale ligure e sul margine della Calabria Ionica, in $24^{\circ}$ Convegno Nazionale Gruppo Nazionale di Geofisica della Terra Solida, edited by D. Sleijko and A. Rebez, 301-304, Roma, 15-17 Novembre 2005, 2005.

Corsini, S., F. Guiducci, and R. Inghilesi, Statistical extreme wave analysis of the Italian Sea Wave Measurement Network Data in the period 19891999, Servizio Idrografico e Mareografico Nazionale, Dipartimento per i Servizi Tecnici Nazionali, Rome, Italy, 2002.

Del Gaudio, V., P. Pierri, G. Calcagnile, and N. Venisti, Characteristics of the low energy seismicity of central Apulia (southern Italy) and hazard implications, J. Seismol., 9, 39-59, 2005.

De Rosis, L., Descrizione del tremuoto avvenuto in aprile del 1836, in Cenno storico della città di Rossano e delle sue nobili famiglie, libro I, 88-112, Napoli, 1838 (in Italian). 
Di Bucci, D., S. Coccia, U. Fracassi, V. Iurilli, G. Mastronuzzi, G. Palmentola, P. Sansò, G. Selleri, and G. Valensise, Late Quaternary deformation of the southern Adriatic foreland (Southern Italy) from mesostructural data: preliminary results, Italian J. Geosci. (Bollettino della Società Geologica Italiana), 128(1), 33-46, 2009.

Di Bucci, D., R. Caputo, G. Mastronuzzi, U. Fracassi, G. Selleri, and P. Sansò, First evidence of Late Quaternary tectonics from joint analysis in the southern Adriatic foreland (Italy), J. Geodyn., 51, 141-155, 2011.

Dollar, S. J., Wave stress and community structure in Hawaii, Coral Reefs, 1, 71-81, 1982.

Dollar, S. J. and G. W. Tribble, Recurrent storm disturbance and recovery: a long-term study of coral communities in Hawaii, Coral Reefs, 12, 223233, 1993.

Felton, E. A., K. A. W. Crook, and B. H. Keating, The Hulopoe Gravel, Lanai, Hawaii, new sedimentological data and their bearing on the "giant wave" (mega-tsunami) emplacement hypothesis, Pure Appl. Geophys., 157(6-8), 1257-1284, 2000.

Ferranti, L., F. Antonioli, B. Mauz, A. Amorosi, G. Dai Prà, G. Mastronuzzi, C. Monaco, P. Orrù, M. Pappalardo, U. Radtke, P. Renda, P. Romano, P. Sansò, and V. Verrubbi, Markers of the last interglacial sea level high stand along the coast of the Italian Peninsula: Tectonic implications, Quatern. Int., 145-146, 30-54, 2006.

Galvin, C. J., Wave breaking in shallow water, in Waves on Beaches and Resulting Sediment Transport, edited by R. E. Meyer, pp. 413-456, Academic Press, New York, 1972.

Goto, K., S. A. Chavanich, F. Imamura, P. Kunthasap, T. Matsui, K. Minoura, D. Sugawara, and H. Yanagisawa, Distribution, origin and transport process of boulders deposited by the 2004 Indian Ocean tsunami at Pakarang Cape, Thailand, Sediment. Geol., 202, 841-837, 2007.

Goto, K., T. Kawana, and F. Imamura, Historical and geological evidence of boulders deposited by tsunami, Southern Ryukyu Islands, Japan, Earth-Sci. Rev., 102(1-2), 77-99, 2010.

Gruppo di Lavoro CPTI, Catalogo Parametrico dei Terremoti Italiani, versione 2004 (CPTI04), Istituto Nazionale di Geofisica e Vulcanologia, Bologna, http://emidius.mi.ingv.it/CPTI/, 2004

Hall, A. M., J. D. Hansom, D. M. Williams, and J. Jarvis, Distribution, geomorphology and lithofacies of cliff-top storm deposits: Examples from the high-energy coasts of Scotland and Ireland, Mar. Geol., 232, 131-155, 2006.

Hansom, J. D., N. D. P. Barltrop, and A. M. Hall, Modelling the processes of cliff-top erosion and deposition under extreme storm waves, Mar. Geol., 253, 36-50, 2008.

Hearty, J. P., Boulder deposits from large waves during the last interglaciation on North Eleuthera Island, Bahamas, Quatern. Res., 48, 326-338, 1997.

Holliday, N. P., M. J. Yelland, R. Pascal, V. R. Swall, P. K. Taylor, C. R. Griffiths, and E. Kent, Were extreme waves in Rockall Though the largest ever recorded?, Geophys. Res. Lett., 33, L05613, 2006.

Istituto Idrografico della Marina, Il vento e lo stato del mare lungo le coste italiane e dell'Adriatico, Istituto Idrografico della Marina, Genova, III, 1982 (in Italian).

Jenny, S., S. Goes, D. Giardini, and H.-G. Kahle, Seismic potential of Southern Italy, Tectonophysics, 415(1-4), 81-101, 2006.

Kelletat, D. and G. Schellmann, Tsunami in Cyprus field evidences and ${ }^{14} \mathrm{C}$ dating results, Zeitschrift für Geomorphologie, $N F$, Supplementband, 46(1), 19-34, 2002.

Kelletat, D., A. Scheffer, and S. Scheffers, Paleo-tsunami relics on the southern and central Antillean island arc (Grenada, St. Lucia and Guadalupe), J. Coast. Res., 21(2), 263-273, 2005.

Keulegan, G. H. and G. W. Patterson, Mathematical theory of irrotational translation waves, J. Res. Natl. Bur. Stand., 24, 47-101, 1940.

Laborel, J. and F. Laborel-Deguen, Biological indicator of relative sealevel variations and co-seismic displacements in the Mediterranean Region, J. Coast. Res., 10(2), 395-415, 1994.

Lambeck, K., F. Antonioli, A. Purcell, and S. Silenzi, Sea-level change along the Italian coast for the past 10,000 yr, Quat. Sci. Rev., 23, 15671598, 2004.

Lavigne, F., R. Paris, P. Wassmer, C. Gomez, D. Brunstein, D. Grancher, F. Vautier, J. Sartohadi, A. Setiawan, T. G. Syahnan, B. W. Fachrizal, D. Mardiatno, A. Widagdo, R. Cahyadi, N. Lespinasse, and L. Mahieu. Learning from a major disaster (Banda Aceh, December 24th, 2004): A methodology to calibrate simulation codes for tsunami inundation models, Zeitschrift für Geomorphologie, NF, Supplementband, 146, 3$265,2006$.

Maouche, S., C. Morhange, and M. Megharoui, Large boulder accumulation on the Algerian coast evidence tsunami events in the Western
Mediterranean, Mar. Geol., 262, 96-104, 2009

Massel, S. R., Prediction of the largest surface wave height in water of constant depth, in Recent Advanced in Marine Science and Technology, edited by N. Saxena, 96, pp. 141-151, PACON International, Honolulu, USA, 1997.

Mastronuzzi, G., Tsunami in Mediterranean sea, Egyptian J. Environ. Change, 2(1), 1-9, 2010.

Mastronuzzi, G. and C. Pignatelli, Determination of tsunami inundation model using terrestrial laser scanner techniques, in The Tsunami Threat, Research and Technologies, edited by N.-A. Mörner, pp. 219-236, INTECH, INTECHWEB.ORG, 2011.

Mastronuzzi, G. and P. Sansò, Morfologia e genesi delle isole Cheradi e del Mar Grande (Taranto, Puglia, Italia), Geografia Fisica e Dinamica Quaternaria, 21, 131-138, 1998 (in Italian with abstract in English).

Mastronuzzi, G. and P. Sansò, Boulders transport by catastrophic waves along the Ionian coast of Apulia (Southern Italy), Mar. Geol., 170, 93103, 2000.

Mastronuzzi, G. and P. Sansò, Large boulder accumulations by extreme waves along the Adriatic coast of southern Apulia (Italy), Quatern. Int., 120, 173-184, 2004.

Mastronuzzi, G. and P. Sansò, Risk assessment of catastrophic waves impacts on coastal environment, Geografia Fisica e Dinamica Quaternaria, 29(1), 83-91, 2006.

Mastronuzzi, G., C. Pignatelli, and P. Sansò, Boulder fields: A valuable morphological indicator of paleotsunami in the Mediterranean Sea, Zeitschrift für Geomorphologie, NF Supplementband, 146, 173-194, 2006.

Mastronuzzi, G., C. Pignatelli, P. Sansò, and G. Selleri, Boulder accumulations produced by the 20th February 1743 tsunami along the coast of southeastern Salento (Apulia region, Italy), Mar. Geol., 242(1), 191205, 2007a.

Mastronuzzi, G., Y. Quinif, P. Sansò, and G. Selleri, Middle-Late Pleistocene polycyclic evolution of a geologically stable coastal area (southern Apulia, Italy), Geomorphology, 86, 393-408, 2007b.

Moberly, R. and T. Chamberlain, Hawaiian beach systems, Hawaii Institute of Geophysics, University of Hawaii, Honolulu, HI, Report HIG642, 1964.

Moore, J. G. and G. W. Moore, Deposit from a giant wave on the island of Lanai, Hawaii, Science, 226, 1311-1315, 1984.

Morhange, C., N. Marriner, and P. A. Pirazzoli, Evidence of Late-Holocene Tsunami Events in Lebanon, Zeitschrift für Geomorphologie, NF, Supplementaband, 146, 81-95, 2006.

Noormets, R., K. A. W. Crook, and E. A. Felton, Sedimentology of rocky shorelines: 3. Hydrodynamics of megaclast emplacement and transport on a shore platform, Oahu, Hawaii, Sediment. Geol., 172, 41-65, 2004.

Nott, J., Extremely high wave deposits inside the Great Barrier Reef, Australia; determining the cause tsunami or tropical cyclone, Mar. Geol., 141, 193-207, 1997.

Nott, J., Waves, coastal boulders and the importance of the pre-transport setting, Earth Planet. Sci. Lett., 210, 269-276, 2003.

Pignatelli, C., P. Sansò, and G. Mastronuzzi, Evaluation of tsunami flooding using geomorphologic evidence, Mar. Geol., 260, 6-18, 2009.

Pignatelli, C., A. Piscitelli, B. Damato, and G. Mastronuzzi, Estimation of the value of Manning's coefficient using Terrestrial Laser Scanner techniques for the assessment of extreme waves flooding, Zeitschrift für Geomorphologie, NF, Supplementaband, 54(3), 317-336, 2010.

Pondrelli, S., A. Morelli, G. Ekström, G. Mazza, E. Boschi, and A. M. Dziewonski, European-Mediterranean regional centroid-moment tensors: 1997-2000, Phys. Earth Planet. Inter., 130, 71-101, 2002.

Romano, M., Relazione del Sindaco Michele Romano al Sottintendente del distretto sul terremoto del 25 aprile 1836, in Deliberazioni del Decurionato (1834-1836), Archivio Storico del Comune di Rossano, Cosenza, 10 luglio 1836 (in Italian).

Rossi, A. A., De' tremuoti nella Calabria Citeriore 1'anno 1836, Annali Civili del Regno delle Due Sicilie, 12(23), 12-34, Napoli, 1836 (in Italian).

Rossi, A. A., Stora dei tremuoti di Calabria negli anni 1835 e 1836, Napoli, 1837 (in Italian).

Scheffers, A., Paleotsunami in the Caribbean: field evidences and datings from Aruba, Curaçao and Bonaire, Essener Geographische Arbeiten, 33, $181,2002$.

Scheffers, A., Tsunami imprints on the Leeward Netherlands Antilles (Aruba, Curaçao and Bonaire) and their relation to other coastal problems, Quatern. Int., 120(1), 163-172, 2004.

Scheffers, A. and S. Scheffers, Tsunami deposits on the coastline of west Crete (Greece), Earth Planet. Sci. Lett., 259, 613-624, 2007. 
Scicchitano, G., C. Monaco, and L. Tortorici, Large boulder deposits by tsunami waves along the Ionian coast of south-eastern Sicily (Italy), Mar. Geol., 238, 75-91, 2007.

Soloviev, S. L., Tsunamigenic zones in the Mediterranean Sea, Nat. Haz., 3, 183-202, 1990.

Stuiver, M. and P. Reimer, Calib 6.0 software, http://radiocarbon. pa.qub.ac.uk/calib/, 2010.

Switzer, A. D. and J. M. Burston, Competing mechanisms for boulder deposition on the southeast Australian coast, Geomorphology, 114, 4254, 2010.

Tinti, S. and A. Maramai, Catalogue of tsunamis generated in Italy and in Cote d'Azur, France: a step towards a unified catalogue of tsunamis in Europe, Annali di Geofisica, 39, 1253-1299, 1996.

Tinti, S., A. Maramai, and L. Graziani, The new catalogue of Italian tsunamis, Nat. Haz., 33, 439-465, 2004.
Vött, A., M. May, H. Brückner, and S. Brockenmüller, Sedimentary evidence of Late Holocene tsunami in Lefkada Island (NW Greece), Zeitschrift für Geomorphologie, NF, Supplementband, 146, 139-172, 2006.

Whelan, F. and D. Kelletat, Analysis of tsunami deposits at Cabo de Trafalgar, Spain, using GIS and GPS technology, Essener Geographische Arbeiten, 35, 11-25, 2003.

Williams, D. M. and A. M. Hall, Cliff-top megaclast deposits of Ireland, a record of extreme waves in the North Atlantic-storms or tsunamis?, Mar. Geol., 206, 101-117, 2004.

G. Mastronuzzi (e-mail: giuseppeantonio.mastronuzzi@uniba.it) and C. Pignatelli 